\title{
Early Cantos I-XLI
}

\section{Citation}

Albright, Daniel. 1999. Early Cantos I-XLI. In The Cambridge Companion to Ezra Pound, ed. Ira B. Nadel, 59-91. Cambridge: Cambridge Univ. Press.

\section{Published Version}

http://dx.doi.org/10.1017/CCOL0521431174.004

\section{Permanent link}

http://nrs.harvard.edu/urn-3:HUL.InstRepos:3355470

\section{Terms of Use}

This article was downloaded from Harvard University's DASH repository, and is made available under the terms and conditions applicable to Other Posted Material, as set forth at http:// nrs.harvard.edu/urn-3:HUL.InstRepos:dash.current.terms-of-use\#LAA

\section{Share Your Story}

The Harvard community has made this article openly available.

Please share how this access benefits you. Submit a story.

\section{Accessibility}




\section{Daniel Albright}

University of Rochester

\section{EARLY CANTOS I-XLI}

Here begins the great unwieldy poem, all light and mud, to which Ezra Pound devoted much of his life. It was the work of a poet too ambitious, too afraid of being cramped, to work according to a plan. Instead of a plan, Pound devised new Cantos out of his schemes to make sense of his of old Cantos, so that the story of the Cantos comprises two intertwined stories, one concerning Pound's writing of the poem, the other concerning Pound's interpretations of what he had already written.

This twin story begins in 1915, when Pound was thirty years old, and felt that it was time to write a grand poem worthy of Homer and Dante. As early as 1909, Pound told his mother that he intended to write an epic; but he was not immediately certain how to proceed. In 1915 he wrote a long poem, ultimately published in 1917 in Poetry magazine as Three Cantos--a poem quite different from any of the cantos as we know them today. It is characteristic of Pound that he had to erase the beginning of the Cantos, since his whole career is a structure of reinterpretation, often of repudiation, of his earlier work. The sequence of Pound's Cantos feels like a live thing, interrogating itself, casting off outworn versions of itself.

In 1915, Pound could already present himself as the most versatile and accomplished translator in English: even today, translations of Old English tend to echo (or play off) the abrupt, overstressed voice that Pound established in 1911 in "The Seafarer" ("Known on my keel 
many a care's hold, / And dire sea-surge, and there I oft spent / Narrow nightwatch nigh the ship's head"); and the Chinese translations of his 1915 volume Cathay seemed to display a delicacy of diction new to our language. But Pound's original work was less prepossessing. He had written some fine passages in a somewhat nervously archaic idiom, as well as many of the small, tense, sometimes satirical poems, not at all archaic, that were to be collected in the volume Lustra (1916), such as "In a Station of the Metro" (1913). In 1914 Pound explained his compositional procedure:

Three years ago in Paris I got out of a "Metro" train at La Concorde, and saw suddenly a beautiful face, and then another and another, and then a beautiful child's face, and then another beautiful woman, and I tried all that day to find words for what this had meant to me, and I could not find any ... And that evening, as I went home along the Rue Raynouard, I was still trying, and I found, suddenly, the expression. I do not mean that I found words, but there came an equation ... not in speech, but in little splotches of colour. It was just that--a "patttern," or hardly a pattern, if by "pattern" you mean something with a repeat in it. . . if I had the energy to get paints and brushes and keep at it, I might found a new school of painting, of "non-representative" painting, a painting that would speak only by arrangements of colour. . . .

The "one image poem" is a form of super-position, that is to say it is one idea set on top of another. I found it useful in getting out of the impasse in which I had been left by my Metro emotion. I wrote a thirty-line poem, and destroyed it because it was what we call work "of second intensity." Six months later I made a poem half that length; a year later I made the following hokku [haiku]-like sentence:--

"The apparition of these faces in the crowd:

Petals, on a wet, black bough.” (EPVA, pp. 203-5)

By eliminating all but the hardest kernel, Pound hoped to find the minimum unit of poetic expression. But this technique, basic to the Imagist movement that Pound helped to establish, 
did not seem promising for an epic poem.

Almost as soon as the Imagist movement began, Pound sought for ways of extending the poetic image without losing its concentration. The Vorticist movement of 1914 sought ways of embodying in a poem, not just the image itself, but the process through which the image was conceived and transmitted: "The image . . . is a radiant node or cluster; it is what I can, and must perforce, call a VORTEX, from which, and through which, and into which, ideas are constantly rushing. In decency one can only call it a VORTEX" (EPVA, p. 207). The notion of a whirl of ideas fining themselves down, focusing on some central point, seems more useful to an epic poet than the notion of an interminable gallery of terse and disconnected images--pattern-units in the absence of a pattern. But how was Pound to write an epic in the form of a tornado?

\section{Three Cantos (1917)}

In a sense, the Pound of 1915 did not want to ask himself such questions; he simply wanted to write, and to write without any particular sense of a model. His very choice of the word canto to describe his poem is intriguing. Canto is simply an Italian word for song, but in English it suggests a chunk of a single long poem, such as Homer's Odyssey or Dante's Divine Comedy. But Pound used the word ambiguously: the English sense is not quite right, for the theme of the whole, the form of the whole, the destination of the whole--none of these was determined when he began; the whole was to be a construct of the parts, and so each Canto had to claim a certain independence, a certain authority in solitude. And the Italian sense is not quite right either, for the song-like passages are intermixed with material extremely hard to sing, such as excerpts from the letters of Thomas Jefferson. The word canto is an impudence: an allegation of a comprehensiveness of design that was never likely to be evident--though Pound hoped that some day, somehow, it would be achieved; and an allegation of music that indeed can be heard, but only fitfully, as if the whole poem were a transcript of a radio broadcast that kept losing the 
proper channel, dissolving into static, or into the blare of the aggressive wrong stations occupying a bandwidth close to the faint right station.

The choice of the word canto arouses certain expectations in the reader, perhaps most of all that expectation that the poem is a Divine Comedy for the Modernist age. Pound sometimes invited this, and sometimes resisted this. In 1915 Pound wrote, "I am working on a long poem which will resemble the Divina Commedia in length but in no other manner . . . it will prevent my making any money for the next forty years, perhaps" $(P / A C H$, p. 120); but in 1917 , when Harriet Monroe was printing (contrary to his wishes) Three Cantos in installments, Pound wrote, "Have at last had a letter from Harriet, consenting to print the Divina Commedia, in three sections" $(P / A C H$, p. 223). The premise of Dante's poem, of course, is a series of interviews between a character named Dante, a tourist in the afterlife during the year 1300, and various dead souls, whose torture or beatitude takes the form of a certain expressive urgency: they boast, they exhort, they weep, they sing. There are a few passages in Pound's Cantos which closely follow Dante's premise:

Exuded the great usurer Geryon, prototype of Churchill's bankers. And there came singing Filippo Tomaso in rough dialect, with $\mathrm{h}$ for $\mathrm{c}$, all right, I am dead, but do not want to go to heaven,

I want to go on fighting \& I want your body to go on with the struggle. And I answered: "my body is already old, I need it, where wd. I go?

But I will give you a place in a Canto ... $\&$ leave the talking to me. And let me explain, 
between light and mud. ( $C$ LXXII/432)

But this eerie encounter between Pound and the Futurist Marinetti occurs in a late Canto, from 1944, originally written in Italian, as if Pound could become Dante only by abandoning the English language. In the early Cantos, we behold glimpses of the torsions of hell and the opalescences of heaven, as Dante conceived them, but Pound's structural technique owes little to Dante.

Pound was reluctant to shape his poem according to classical or medieval European models; and he was also reluctant to shape his poem according to extremely up-to-date Modernist models. The appearance of Marinetti in Canto LXXII suggests, not only an alternate, unwritten version of the Cantos in the style of Dante, but another possible version that Pound might have considered and rejected: Cantos in the style of Marinetti. In 1915, when Pound was beginning the project, Europe was full of experiments in making language look like pictures: in 1914 Apollinaire had begun his Calligrammes (originally called idéogrammes lyriques), and Marinetti published his Zum Tumb Tuum. Apollinaire's early calligram Lettre-océan shows sentences radiating across the page from a center, like radio transmissions from the Eiffel tower; and a page of Marinetti's book takes the words PALLONE FRENATO TURCO (Turkish captive balloon) and prints them in a circle, from which dangle vertical lines of print, representing the ropes that tie the balloon down. In the 1910s Pound tended to be contemptuous of Marinetti, and suspicious of the French experiments with poetic ideograms; on the other hand, he regarded Chinese as a language blessed by its pictorial specificity of meaning, and he noted with awe that the sculptor Gaudier-Brzeska was so sensitive to design that, without having studied Chinese, he could read its ideograms, through sheer power to destylize the signs into pictures $(C W C$, p. 31 ; $A B C R$, p. 21). The Modernist hope of shaping language into typographic forms through which the eye can see the meaning of the text informs some passages in the Cantos:

For the procession of Corpus come now banners 
comes flute tone

to new forest,

$$
\text { thick smoke, purple, rising }
$$

bright flame now on the altar

the crystal funnel of air

out of Erebus, the delivered,

Tyro, Alcmene, free now, ascending

e i cavalieri

$$
\text { ascending, }
$$

no shades more,

lights among them, enkindled ... (C XC/628-29)

Here is a passage arranged in the shape of a vortex, through which and into which ideas constantly rush: the syntax, the spatial arrangement of the words, seem to shape a funnel on the page, as the participles at the line-breaks push the verbal flow back to the left-hand margin. But this is from a very late Canto, published in 1955--in many of the late Cantos, Pound seems to be experimenting with compositional procedures unused in the bulk of the poem. For the most part, neither Dante nor Marinetti, neither the old nor the modish, gave Pound what he needed for his great project.

Despite Pound's unwillingness to limit his field of poetic operation by planning, Three Cantos (1917) did make use of a model--a model that no other poet on earth would have chosen as the basis of a long Modernist poem: Sordello (1840), an overwhelmingly ambitious poem by the very young Robert Browning, published at his father's expense. Sordello soon became a byword for gnarled and willful obscurity; Tennyson noted that he could understand only two of the poem's approximately six thousand lines, the very first ("Who will, may hear Sordello's story 
told") and the very last ("Who would has heard Sordello's story told")--unfortunately, he felt, both lines were lies (Martin, Tennyson: The Unquiet Heart, p. 302). Still, the first words given to the world from Pound's Cantos consisted of a tribute to Sordello:

Hang it all, there can be but one Sordello!

But say I want to, say I take your whole bag of tricks,

Let in your quirks and tweeks, and say the thing's an art-form

Your Sordello, and that the modern world

Needs such a rag-bag to stuff all its thought in;

Say that I dump my catch, shiny and silvery

As fresh sardines flapping and slipping on the marginal cobbles?

(I stand before the booth, the speech; but the truth

Is inside this discourse--this booth is full of the marrow of wisdom).

Give up th' intaglio method. (Bush, Genesis, p. 53)

The ejaculative, impertinent tone of this passage is itself borrowed from Browning--but Browning's persona was only one of several features that attracted Pound to Sordello. Pound liked Browning's way of resurrecting the past--the historical Sordello was a thirteenth-century troubadour who eloped with Cunizza da Romana, a nobleman's wife--by means of a modern intermediary, who dramatizes himself in the act of dramatizing long-extinct characters. Indeed Browning introduces himself to the reader as a sort of professor dressed like a clown:

Motley on back and pointing-pole in hand ...

So, for once I face ye, friends . . .

Confess now, poets know the dragnet's trick,

Catching the dead, if fate denies the quick ...

What heart

Have I to play my puppets . . . ? (Sordello I 30, 31, 35-36, 71-71)

Throughout the Three Cantos, Pound, following the Browningesque model of puppet-master, 
plays the genial but erratic impresario, making his pretty merchandise dance for public admiration--glances at the pomp of Italian and Spanish parades, snatches from Catullus and the story of el Cid, memories of his 1908 trip to Venice, all shot through with visions of old gods taking shape in the air. It is a self-conscious, theatrical sort of poetizing, which at last terminates in the third of the Three Cantos, when the poet opens an old book, Andreas Divus's Latin translation (1538) of the Odyssey, and gently complains about the hard work of translating, whether from Latin or Provençal:

I've strained my ear for -ensa, -ombra, and -ensa

And cracked my wit on delicate canzoni--

Here's but rough meaning:

"And then went down to the ship, set keel to breakers,

Forth on the godly sea;

We set up mast and sail on the swarthy ship ... (Bush, Genesis, pp. 69-70)

The reader will recognize the section in quotation marks as a draft of Canto I, as it would appear in A Draft of XVI Cantos (1925), and as it appears today. During the eight years between the composition of Three Cantos and the recasting of Canto I in 1923, a tremendous reorientation had occurred in Pound's poetics; and his idea of what a Canto was had shifted so greatly that he found himself simply emancipating the translation of Odysseus's descent to Hades from all the masses of prefatory material. Pound took a flensing knife to Three Cantos; but in order to do so he needed to devise a clear principle for distinguishing meat from blubber.

Three Cantos is a work with deep focal field. In the foreground is the poet, the showman with his sardines; in the middle ground are exhilarating landscapes, like those Tuscan climes where "The senses at first seem to project for a few yards beyond the body" (LE, p. 152); in the background is a tissue of reminiscence of art and literature, from Botticelli to Egyptian inscription. In 1915 Pound conceived an epic as a careful mediation between a central consciousness surrounding, animating, swirling into, receding from, the brief stories and the 
descriptions of the text--as Joyce put it in A Portrait of the Artist as a Young Man, to be published the following year, in the epic "The personality of the artist passes into the narration itself, flowing round and round the persons and the actions like a vital sea" (p. 214). Pound regarded his work as something far choppier, more discontinuous, than the old epics--as he expostulated to Browning in Three Cantos I,

You had one whole man?

And I have many fragments, less worth? . . .

Ah, had you quite my age, quite such a beastly and cantankerous age?

You had some basis, had some set belief. (Bush, Genesis, p. 54)

But Pound may have felt that the very fragmentariness of the modern age required the emollience of a clearly present core sensibility, absorbing all the fragments into a single matrix, preventing their rough edges from cutting the reader. Pound compared the Three Cantos to a "rag-bag"; one might also think of chunks of fruit suspended in the jello of the poet's mind.

But there were certain obvious dangers in entrusting the great project of one's life to a model of fragments stuck in a rag-bag. Any fragment, any bright pebble that catches the eye, is as good as any other, unless some method can be found for discriminating the Luminous Detail $(S P$, p. 22) from the general muck. And just as the contents of the Cantos were looking ominously random, so the coordinating sensibility, the mind of Pound, also seemed incoherent. Poggio, in Pound's dialogue "Aux Etuves de Wiesbaden" (1918), notes "They ruin the shape of life for a dogmatic exterior. .. . I myself am a rag-bag, a mass of sights and citations, but I will not beat down life for the sake of a model" (PDD, p. 102). This makes a noble affirmation of a shapeless self and codeless conduct--but it seems to lead to the opposite of art, insofar as art represents selection, intensification, concinnity. In 1920 Pound reviewed the list of personae in his poetry, and noted that, while Propertius, the Seafarer, and Mauberley "are all 'me' in one sense; my personality is certainly a great slag heap of stuff which has to be excluded from each 
of th[ese] crystalizations" $(P / F$, p. 42$)$. At that time Pound was trying to decide how to proceed with the Cantos, and it is easy to see why he was uncertain: no single persona was inclusive enough to be the Sordello of the Modernist age; but to present the whole "slag heap" was simply to present something bulging and ugly, the detritus of self instead of the informing force. The road of the Three Cantos leads to self-insistence, gigantism, Wagnerian opera, and general uffishness and whiffling--not the goals that Pound sought. Instead of giving up the intaglio method--carefully chiseled art--Pound needed to find a way of integrating epic aspirations with incisive design.

\section{Cantos IV-VII (1919)}

The Cantos got on the right path (from Pound's point of view) in 1919, when he wrote Canto IV--the first Canto that he regarded as capable of standing in the finished sequence, although it too was revised to some degree. Canto IV has an entirely different texture from the Three Cantos of 1917.

Instead of the carefully modeled perspective drawing of the Three Cantos, where the reader is oriented in psychological space, we now have a flat field. The poet, the events, the literary allusions, all co-exist on the same plane:

And she went toward the window and cast her down,

"All the while, the while, swallows crying:

Ityn!

"It is Cabestan's heart in the dish."

"It is Cabestan's heart in this dish?

"No other taste shall change this."

And she went toward the window,

the slim white stone bar 
Making a double arch...

and the wind out of Rhodez

Caught in the full of her sleeve.

. . . the swallows crying:

'Tis. 'Tis. Ytis! ...

Then Actæon: Vidal,

Vidal. It is old Vidal speaking,

stumbling along in the wood...

The pine at Takasago

grows with the pine of Isé!

The water whirls up the bright pale sand in the spring's mouth

"Behold the Tree of the Visages!" . . .

The Centaur's heel plants in the earth loam.

And we sit here...

there in the arena... (C IV/13-16)

This is only a condensation of Canto IV, but it is faithful to the hard edges of Pound's transitions: the slabs of texts abut one another without much sense of a professor, or clown, or master of ceremonies creating a steady context for the evolution of the pictures and stories. The last two lines did not appear in the text until 1925--originally the poet scarcely had any presence in the poem. But even this final allusion to the premise of Three Cantos I--the showman-poet sitting in "the old theatre at Arles" (Bush, Genesis, p. 57) and conjuring visions--does not succeed in producing a graduated field with the poet's intelligence on one plane and the stories and pictures on another. Instead the snapshot of poet in arena is just another pictorial element of the collage. Pound has cast off "Bob Browning" in favor of a different structural model. The key to the method of Canto IV lies in the section about the pines of Takasago and Isé: Pound has turned to the Orient to reorient his poem. In an undated letter, Pound told Harriet Monroe that the 
theme of the Cantos is "roughly the theme of 'Takasago,' which story I hope to incorporate more explicitly in a later part of the poem" $(P / A C H$, p. xxii). This may suggest that even during the composition of Three Cantos, Pound considered the Japanese Noh play, and specifically the Noh play Takasago, as crucial to the whole project. In Three Cantos Pound made some picturesque allusions to the Noh theatre; but Canto IV suggests that the Cantos could aspire, not simply to include pretty elements of Japanese theatre, but to be a kind of Noh play.

Pound spent his winters at Stone Cottage in Sussex from 1913 to 1916, working with Yeats on (among other things) the possibilities for finding a Western equivalent to the classic Noh theatre of Japan. The Noh is, by Western standards, a theatre without drama. There is rarely anything that could be called a story; the action, which is minimal, is usually accomplished during, and by means of, the climactic dance. In the simplest plays a travelling priest (called the waki), often a folklorist or a connoisseur of landscape, meets a humble old man or old woman; after a series of interrogations it dawns on the priest that what appears to be a vagrant, a beggar, or a leech-gatherer, is actually a spirit (called the shite)--perhaps the ghost of a great man triumphantly remembering the scene of a mighty deed, or a genius loci, taking pleasure in the presence of his or her locus. A metamorphosis is accomplished by means of a costume change and a change of mask; there is no scenery, nothing but bridges and potted pines and the painted pinetree that is the backdrop of all Noh plays. The dramatic action, then, is only a movement towards enlightenment: what is surrounded by material illusion at last reveals itself in its true supernatural glory, a glory that reaches its perfection in the characteristic dance of the spirit. It is not the sort of dramatic action that we are accustomed to; but in certain films we find something similar to it. For example, Steven Spielberg's Close Encounters of the Third Kind (1977) is Noh-like in that it has neither heroes nor villains, no action except the tantalizing unveiling of a remarkable and nearly incomprehensible spectacle; since we rarely like, these days, to speak of spirits, Spielberg substitutes an extraterrestrial being, which is all that is acceptable of the otherworldly; where a Noh play would have a climactic dance, Spielberg 
substitutes an increasing visual magnificence of unearthly forms. Spielberg was probably not influenced by Noh drama, but this film and the Noh share a common aesthetic goal, an attempt to provoke a delirium of wonder.

Pound discovered in the Noh an answer to a question that had puzzled him: "I am often asked whether there can be a long imagiste ... poem. The Japanese, who evolved the hokku, evolved also the Noh plays. In the best 'Noh' the whole play may consist of one image. I mean it is gathered about one image. Its unity consists in one image, enforced by movement and music" (EPVA, p. 209). A Noh play is unitary; it is incisive; it is an extended writing, but antidiscursive--a text with the instantaneity and direct grasp of a painting, or an ideogram. These are the very qualities to which the Cantos aspire. Motokiyo's Takasago takes for its "one image" the embrace of two pine trees:

PRIEST.

... Why do they call all the pines in Takasago and in Suminoye "Ai-oi?" the two places are very far distant, and the word means "growing together."

OLD MAN.

Yes, I know anyone can read in the preface of Kokin that "It seems the pine trees of Takasago and Suminoye grow together" but I am a man of Sumiyoshi ... you had better ask the old woman, she's of this place.

PRIEST.

What, I see the old pair here together and yet he says they lives apart, he says he is is of Sumiyoshi!

TSURE.

That's a stupid thing you are saying. Though the mountain and river lie between us we are near in the ways of love... . 
PRIEST.

Yes, but what is the story that you are half telling? . .

TSURE.

Takasago mean the old age of the emperor Manyoshu.

OLD MAN.

Sumiyoshi mean our own time ...

\section{CHORUS.}

Though grass and trees have no mind

They have their time of blossoming and of bearing their fruit ...

\section{OLD MAN.}

And the look of this pine is eternal.

Its needles and cones have one season. (trans. Pound, $P / A C H$, pp. 112-15)

The play is an affront to time and space. The two pines are geographically apart, separated by mountain and river, and yet they clasp; the pine of Takasago symbolizes a past age, and the pine of Sumiyoshi symbolizes the present age, and yet they co-exist. Pound considered Takasago a nearly perfect play, and it demonstrates how the Noh theatre dismantles clock time and yardstick space in order to gesture at some evergreen eternal present, where two pine trees can incarnate themselves as an old man and an old woman, a panpsychic field at the end of all metamorphoses.

Pound tried his hand at writing original Noh plays. His most interesting attempt was Tristan (1916), evidently inspired by a performance of Wagner's Tristan und Isolde conducted by Beecham. It opens with a Prologue, in which the audience in asked to imagine a shore and a 
ruined castle; a Sculptor (the waki) enters, looking for a certain quince tree, a botanical wonder that blossoms in Cornwall (due to the Gulf Stream, he thinks) before any other quince tree. This premise is derived from an episode from the life of the sculptor Gaudier-Brzeska:

Gaudier had been through Wales. He had made a particular pilgrimage to a certain tree, that blooms on a set day in the year because of the warmth of the Gulf-stream. (This might be out of a Japanese "Noh" play, but it isn't.) (GB, p. 76)

In the play, the Sculptor finds an enigmatic woman (the shite), who tries to shoo him away, then vanishes herself; and soon he finds himself witnessing a spectacle in which the shite, now dressed in brilliant Medieval costume, performs a series of slow passes and re-passes with a man, Tristan. Their costumes are gray on one side, so that when they turn round they become invisible against the gray background; thus, from the Sculptor's and the audience's point of view, they seem spectral presences, dissolving and reforming in a slow stately dance. "They flash and fade through each other," the Sculptor says; and Tristan tells Isolde, who is herself having trouble seeing him:

Your eyes ...

(forte, making use of the Sculptor's voice) like malachite gone transparent. . . .

My dust is a veil in the wind

So frail a thing, that you will turn your head,

And look at any fool in a daze,

And not hear me. (PMN, p. 36)

Without using any of the resources of technological illusion (slide projectors or transparent scrims) Pound managed to create a theatre of dematerialization, ghost-glimpses, passions detached from finite human beings and personified into visionary presences.

What would it be like to be inside an imagist's image? Pound's Tristan suggests an answer: it would be a condition where nothing is solid, nothing is determinate--a condition at the knife-edge, at the metamorphic quick, where the subway train is just about to turn into the black 
bough. Pound's play is a theatrical presentation of life inside Wagner's Tristan chord, a chord that demands harmonic resolution yet remains suspended, incapable of resolving, incapable of construing itself, at once creeping upward and diminishing ever further into its own private hypospace--an endless frustration. Because the whole spectacle is one image, the whole action is only the arbitrary spinning-out of a multi-dimensional stasis into a metamorphosis.

Canto IV ends with the poet sitting in an old arena because the poem is itself a kind of theatre--a composite Noh play, made up of several dissected and reassembled fragments of shape-change stories. There is the Baucis and Philemon story from Takasago; there is Actaeon, the peeping-Tom who spied Artemis naked in her bath, then was transformed into a stag and torn apart by Artemis's hounds; there is the lycanthrope troubadour Peire Vidal, who outfitted himself with a wolfskin out of love for a woman named Loba (she-wolf); there is Philomela, changed into a singing bird after her brother-in-law Tereus raped her and cut out her tongue--as revenge, her sister Procne killed Tereus's (and her own) son Itys, cooked him, and served the hideous meal to Tereus; there is the troubadour Cabestanh, murdered by his lord after Cabestanh slept with the lord's wife Seremonda--the lord commanded Cabestanh's heart to be served to her in a dish, and she leaped out a window to her death ( $S R$, p. 44). Pound cunningly arrests and arranges these bright shards of narratives in such a way that they seem all part of a single incurved action: Seremonda is a second Tereus in that she eats human flesh without knowing it, but a second Philomela in that she takes to the air, swings herself out the window like a bird; Actaeon the stag and Vidal the wolf seem part of a single action, a sexual urgency that either flees or attacks, depending on the quality of desire. The Noh theatre provided Pound with a model for manifesting the approach through time and space of some whole beyond time and space--a complex that the poet inspects glint by glint, ply by ply. The pine of Takasago and the pine of Isé are, in some occult sense, intertwined at the root; and so are Philomela and Seremonda and Tereus and Vidal. 
Canto IV was published in October 1919; in December of that year Pound wrote Cantos V-VII, not published until 1921. Pound was concerned about their obscurity, with reason:

And Pieire won the singing, Pieire de Maensac,

Song or land on the throw, and was dreitz hom

And had De Tierci's wife and with the war they made:

Troy in Auvergnat

While Menelaus piled up the church at port

He kept Tyndarida. Dauphin stood with de Maensac.

John Borgia is bathed at last. (Clock-tick pierces the vision) ...

But Varchi of Florence,

Steeped in a different year, and pondering Brutus . . .

"Whether for love of Florence," Varchi leaves it, Saying "I saw the man, came up with him at Venice,

"I, one wanting the facts,

"And no mean labour... Or for a privy spite?"

Our Benedetto leaves it,

But: "I saw the man. Se pia?

"O empia? For Lorenzaccio had thought of stroke in the open ..."

Schiavoni... cloak... "Sink the damn thing!"

Splash wakes the chap on the wood-barge. $(C \mathrm{~V} / 18-20)$

When Amy Lowell read this--she had quarreled with Pound concerning her appropriation of the term imagism for her own purposes--she turned the first passage into rhymed couplets:

There is Pierre de Maensac, and Pierre won the singing--

Where or how I can't guess, but Pound set his fame ringing

Because he was dreitz hom (whatever that is) 
And had De Tierci's wife; what happened to his

We don't know, in fact we know nothing quite clearly,

For Pound always treats his ghosts cavalierly.

(Ruthven, A Guide to Ezra Pound's Personae, p. 203)

For some readers, Lowell will always have the last word on Canto V.

Canto V is like Canto IV, in that the world of troubadour adultery is still evoked for its glamours, and in that short segments are spliced together to reveal common themes. The singer Pierre de Maensac may be a dreitz hom (straight guy), but he was nonetheless devious enough to run off with De Tierci's wife--a second Paris abducting a second Helen from a second Menelaus. But Canto V also represents an important departure in style. Even as early as Canto I--which, it must be remembered, did not yet exist, except as the coda of Three Cantos III--Pound liked to conjure up some secondary conjuror, such as Andreas Divus, to do the work of conjuring in his stead: indeed Pound liked best of all a sort of infinite regression of conjurors, according to which Tiresias's ghost is raised up by Odysseus, and Odysseus is raised up by Homer, and Homer is raised up by Divus, and Divus is raised up by Pound. Benedetto Varchi in Canto V is just such a secondary intelligence, to whom Pound can appeal for help. But Varchi is not a translator, or a visionary, or a mythographer; Varchi is a historian, pondering the morality of a crime: was the murder of Alessandro de' Medici, in 1537, by his cousin Lorenzino de' Medici, pia o empia?-pious or impious? Was the murder a petty revenge, or a noble, Brutus-like attempt to save Florence from tyranny? With Canto V Pound enters history; and with history comes indecision, insecurity of analysis, uncertainty about events themselves. The mythic metamorphoses of Canto IV provide sharp focus and escape from pain; but history provides only blurred interpretations and endless mutation of pain. Pound admired Varchi for his impartiality, his refusal to assert more than he knew; but there is some peril in writing a poem so chaste, so reticent about assertion, that the reader, like Amy Lowell, is left to scratch her head, unable to understand either the meaning of the facts or the facts themselves. 
The other novelty of Canto V is its elaboration of voice. Canto IV is a slide-projection of lovely pictures, an extension of the imagist principle of superposition. But Canto $\mathrm{V}$ is full of the sound of speech, from Varchi's elegant and inconclusive musings to the exclamation "Sink the damn thing!" (concerning the tossing of Giovanni Borgia's corpse into the Tiber, in 1497). Pound filled Three Cantos back in 1917 with all sorts of exclamations ("Hang it all" is the first phrase of the poem), but most of the exclamations are the poet's voice. But by Canto $\mathrm{V}$ the poet's own voice is quiet; and the silence is filled by other voices, loud or whispery. The Cantos will grow still more vociferous as they evolve. In Canto VI, for example, Pound tells the story of the troubadour Bernart de Ventadour: how his music seduced the wife of his patron Eblis III, how Eblis shut up his wife in prison in revenge. But Pound tells the story in Bernart's own voice; and Bernart quotes the Provençal title of the song with which he captivated the wife, 'Que la lauzeta mover' ("When I see the lark a-moving," SR, p. 41). Probably Pound intended the reader to hear Bernart's leaping, subtle melody as an undertone to the words--for the Cantos, the Songs, are now beginning to fill with music. Cantos V and VI resound with intelligent or exuberant voices; by Canto VII, a Canto of old men, grave, withered, the voices have mostly dwindled to a kind of muttering, "Dry casques of departed locusts / speaking a shell of speech . . . The words rattle: shells given out by shells" ( $C$ VII/26-27). The project of the Cantos now seems an attempt to animate a dead or dying language; to remember and re-speak the words of power, spoken long ago but still echoing in the mind.

Though Pound was reluctant to say so in public, the Cantos have a certain aspect of mediumship, as if a poem were a séance through which the voices of the dead could reverberate among the living. In Three Cantos I, Pound wrote, "Ghosts move about me / Patched with histories" (Bush, Genesis, p. 54); and often these ghosts use the poet as a kind of speakingtrumpet. In Pound's very earliest work, there is a sense that the poet must empty himself of identity, until he becomes an achromatic medium, an ectoplasm on which the souls of the great dead can take shape: 
No man hath dared to write this thing as yet,

And yet I know, how that the souls of all men great

At times pass through us,

And we are melted into them, and are not

Save reflexions of their souls.

Thus am I Dante for a space and am

One François Villon, ballad-lord and thief . . .

And as the clear space is not if a form's

Imposed thereon,

So cease we from all being for the time,

And these, the Masters of the Soul, live on. ("Histrion" [1908], CEP, p. 71)

Yeats, of course, spent a great deal of time participating in spiritualist experiments, and the period of Pound's close association with Yeats coincides with the beginning of the Cantos. Pound wrote to his fiancée Dorothy Shakespear in 1913, "I read ghosts to the eagle [Yeats]" (P/DS, p. 274), and also, "As for the soul being 'mixed up' I dare say we've the whole divina commedia going on inside of us" ( $P / D S$, p. 206). When he began the Cantos two years later, he attended to the many voices in the mixed-up soul, to the infernal and heavenly noises all jumbled together within him.

\section{Cantos II, VIII-XI}

During 1920 and 1921 Pound evidently wrote no Cantos. Instead he finished Hugh Selwyn Mauberley--a poem about an ineffectual, morbidly self-involved artist, sometimes regarded as an attempt to dispell the finesses and lethargies that prevented Pound from making much progress on the Cantos. And he wrote an opera, Le testament, devising his own music for texts of François Villon. And he engaged himself with his fellow Modernists, first by arranging 
to meet Joyce at Sirmione, then by performing his famous "Caesarean Operation" on the text of Eliot's The Waste Land. These experiences profoundly changed the future Cantos, and even changed Pound's relationship to the Cantos already written.

The Waste Land follows, to a degree, the model of Cantos V-VII: ragged textual surfaces imprinted with voices ("My nerves are bad to-night"; "Well now that's done: and I'm glad it's over") often juxtaposed abruptly, and interspersed with spangles hinting at a kind of remote aesthetic relief ("Those are pearls that were his eyes"; "Inexplicable splendour of Ionian white and gold"). Indeed The Waste Land, even before Pound started cutting it, almost seemed more a part of the Pound canon than the Eliot canon, due to its piecemeal construction and the failure of the coordinating sensibility to coordinate the parts properly: the role that Varchi plays in Canto V, or that Pound himself plays in the Three Cantos, Tiresias plays in The Waste Land. Eliot's poem was originally titled He Do the Police in Different Voices, and that could also serve as a secret title of the early Cantos as well: for from Canto V onward the Cantos are a set of impersonations, as the poet's voice reels back through history and myth, trying to discover the authentic voice that can rectify the modern world, that can say what the thunder said.

The Waste Land and the Cantos are both comedies, sometimes divine comedies, sometimes hilarious comedies, sometimes sickening comedies, but in all cases the ideal reader is a comedian like Richard Pryor or Robin Williams, an expert vocal mime who can speak the highbrow lines in a highbrow voice ("Go with your lutes, awaken / The summer within her mind, / Who hath not Helen for peer"--C VIII/30), foreign accents in a cartoon voice ("Looka vat youah Trotzsk is done, e iss / madeh deh zhamefull peace!!"--C XVI/74), and the Bronx cheers and backrubbing noises with idiot emphasis ("woh woh araha thumm, bhaaa"-- $C \mathrm{XX} / 93$; "thkk, thgk"--C XXXIX/193). There seems to be no master voice in the Cantos, no default background voice that reliably engages when the vocal tours de force are complete. Indeed, even as early as 1916, Pound talked in the polyvocal style of the Cantos, as Iris Barry noted: "His is almost a wholly original accent, the base of American mingled with a dozen assorted 'English society' and 
Cockney accents inserted in mockery, French, Spanish, and Greek exclamation, strange cries and catcalls, the whole very oddly inflected, with dramatic pauses and diminuendos" (Charles Norman, Ezra Pound, p. 193). Charles Ives--an American composer with several points of resemblance to Pound--once wrote, "I think there must be a place in the soul / all made of tunes" ("The Things Our Fathers Loved," 1917). Pound's soul was made of voices, voices occasionally rising into melody.

But the typical strategy in the Cantos of 1922--the ones then numbered VIII-XII and now numbered II and VIII-XI--is not the choppy polyphony of V-VII; instead Pound develops two sustained voices, that of Acoetes in II and Sigismundo Malatesta in VIII-XI. This is not the method of The Waste Land, even though the first Malatesta Canto begins with the line "These fragments you have shelved (shored)" (C VIII/28)--clearly echoing (to Eliot's displeasure) a famous line at the end of The Waste Land. The Waste Land will remain an abiding presence in the Cantos: a snatch of Eliot's serving-maid is heard in the line "five abortions and died of the last" (C XXXVIII/187), and Pound's line "crab for an eye, and 30 fathoms of fish" $(C$ XXXIX/194) echoes an unused passage from the manuscript of The Waste Land, "Full fathom five your Bleistein lies ... Graves' Disease in a dead jew's eyes! / Where the crabs have eat the lids" (Waste Land Facsimile, p. 119). But the Cantos of 1922 aggressively distance themselves from the procedures of The Waste Land, as if Pound needed to differentiate his work from Eliot's triumph. Eliot gathers fragments to shore against his ruins from all over the place; but Pound, in the Malatesta Cantos, gathers his fragments from one source, the battered Tempio that Malatesta labored to build.

First came the Canto about Acoetes, the humble pilot who found on his boat a surprising passenger, the god Dionysus, first disguised as "a young boy loggy with vine-must" (C II/7); when the boat is hijacked by thugs, eager to sell the young boy into slavery, the god reveals his power in series of dazzling metamorphoses, first summoning from thin air the Bacchic totems 
("hot breath on my ankles, / Beasts like shadows in glass, / A furred tail upon nothingness"--C II/8), then transforming the thugs into monsters ("Black snout of a porpoise / where Lycabs had been . . . Fish-scales over groin muscles"--C II/9). Pound was (justifiably) proud of his accomplishment in this Canto; he even thought of discarding all the previous Cantos and starting the whole project afresh, as if the premise of the Cantos should be Travels with Dionysus: as Pound mused just after finishing the poem, "I dare say it wd. be easier to cut the 7 preceding cantos \& let Acoetes continue = only I dont see how I cd. get him to Bayswater" $(P / F$, p. 67). It should be noted that, at least for a moment, Pound toyed with the notion of the Cantos as a single voyage, evidently beginning in mythic antiquity and continuing to modern times and familiar civilized places. Pound quickly abandoned this scheme, if he ever seriously proposed it; but it is possible that, for Pound, the many sailors of the Cantos--Odysseus, Acoetes, Hanno the Navigator (in Canto XL)--are versions of one sailor, their voyages the scattered traces of one voyage. Eliot noted in the footnote to line 218 of The Waste Land that "Tiresias . . is the most important personage in the poem, uniting all the rest . . . all the women are one woman, and the two sexes unite in Tiresias." Pound would have resisted any attempt to smear away all distinctions from person to person, but the resourceful sailors all share a certain common tonality. Even the Odysseus of the opening of the Cantos does not speak with the pure voice of Homer: he springs from the translation of a translation, "Done into an approximation of the metre of the Anglo-Saxon 'Sea-farer"' (Bush, Genesis, p. 309)--his voice from the beginning has overtones of other farers on other seas.

As Canto II suggests, the Cantos are both an enchantment and a disenchantment. A disenchantment, in that metamorphosis leads ugly things to distend, flatten, bristle, grow scaly, manifest their ugliness: Lycabs with a porpoise-snout has lost his false human face, has shown what he really is. An enchantment, in that metamorphosis is the basic controlling force of human evolution. In 1921--the year before Canto II--Pound wrote:

Let us suppose man capable of exteriorizing a new organ, horn, halo, Eye of Horus. 
Given a brain of this power, comes the question, what organ, and to what purpose?

Turning to folk-lore, we have Frazer on horned gods, we have Egyptian statues . . . Now in a primitive community, a man, a volontaire, might risk it. He might want prestige, authority, want them enough to grow horns and claim a divine heritage, or to grow a cat head ... he would have been deified, or crucified, or possibly both. Today he would be caught for a circus. ...

But man goes on making new faculties ... You have every exploited "hyperæsthesia," i.e., every new form of genius, from the faculty of hearing four parts in a fugue perfectly, to the ear for money ... (PDD, p. 210)

Pound's ultimate hope for the Cantos might have been to hasten the evolution of a new human race, a race that sprouted horns, whiskers, antennae sensitive to divine tremblings in the ether.

The next Cantos turn from myth to history: from Acoetes to the landlocked Odysseus of fifteenth-century Rimini, the warlord Sigismundo Malatesta, ever harassed, ever trying to construct his private Ithaca, the Tempio. These four Cantos are the most coherent, chronologically intelligible sequence in the whole Cantos, until the Chinese dynastic Cantos LIILXI. And yet they are as technically advanced as any of their precedessors.

Pound had been long experimenting with personae that were not (so to speak) wholebody personae, personae in which the poet was completely hidden by the mask: Pound was fascinated by personae in the form of half-masks, in which the poet only partly hid himself. In the year that he began the Cantos, 1915, Pound wrote "Near Perigord," in which the poet dramatizes the difficulty of finding out enough about the belligerent troubadour Bertrans de Born in order to adopt him as a persona: we see Pound gathering puzzling documents, bemusing himself with possible constructions of Bertrans' physical appearance, pretending for a moment to speak in Bertrans' voice, but at last watching the whole charade fall apart into "a broken bundle of mirrors" $(P, 1926$, p. 157). Sigismundo is Pound's most far-reaching experiment with the 
half-mask: Pound prints documents, sometimes in translation, concerning Sigismundo's life (a poem he wrote to his mistress Isotta; instructions concerning his generous patronage of the arts; a gracious letter he received from his son; a description of the bonfire at St. Peter's basilica, in which an effigy of Sigismundo was burnt, following his excommunication by Pope Pius II); but Pound is reluctant to feign Sigismundo's voice, and prefers to let "Sidge" speak for himself. Much of the narrative is told in the third person, but Pound occasionally slips into the first person plural, as if the poet had enlisted in Malatesta's army:

And we beat the papishes and fought

them back through the tents

And he came up to the dyke again

And fought through the dyke-gate

And it went on from dawn to sunset

And we broke them and took their baggage $(C \mathrm{XI} / 48)$

The repeated And suggests the soldiers' inexorable advance. This technique, in which the poet retains a half-anonymous, tentative presence on the fringes of the poem, would persist in the Cantos; for example, in Canto LVI (1940), the excitable poet starts to affiliate his own voice with that of Yuentchang, taking arms against the Mongols:

$\mathrm{Li}, \mathrm{Su}$, Tong and I were four musketeers

We were workmen in the same village we were plain sojers together

If we can take Chantong province, we can take Pekin ( $C \mathrm{LVI} / 308)$

But there is a moment in the Malatesta Cantos, toward the end of Sigismundo's life, when the poet presents himself in a slightly different manner:

and came back with no pep in him

And we sit here. I have sat here 
for forty thousand years $(C \mathrm{XI} / 50)$

This might be the exaggeration of a footsoldier, whose hard life might seem forty thousand years long; but it also might be the voice of the poet of Canto IV, conjuring up the shadows of the fifteenth century in an old arena; and it also might be the voice of Eliot's Tiresias, who sat by Thebes below the wall, and walked among the lowest of the dead. Sometimes Pound's voice is focused through a mask; but sometimes it blurs, grows hollow with echoes, as if a whole Grand Canyon had opened around it. As Sigismundo's dreams crumble, as it becomes clear that his syncretic temple, in which the gods of pagan antiquity would be worshiped along with the Christian god, will never be finished, the poet starts to disengage himself from Sigismundo, to range for new ghosts.

The Malatesta Cantos were among the first written after Pound's opera, Le testament; and in a sense they constitute a kind of opera without music. Le testament has a simple scenario: it is 1462, and Villon, soon to be hanged, is writing his will within hailing distance of a tavern, and a church, and a brothel. Villon, by bequeathing his poems to his friend Ythier, to his aged mother, to the decayed prostitute La Hëaulmiere, endows his otherwise-mute companions with voices; so Villon's testament remembers and preserves a whole culture, in fragments of sound. Pound was by temperament an anthologist: and his books--ABC of Reading, Guide to Kulchur, the Cantos themselves--represent human culture in a severely deleted condition, with all the boring and useless parts omitted. In this sense, Le testament is the opera of mankind, with all the prose left out: tavern, church, brothel, these are the places that matter to all generations. The music is also pared to the bone: it consists typically of simple vocal lines, moving up and down in nonrepetitive patterns, often without sharps or flats, often with a troubadour-like sound--indeed Pound at one point borrowed an actual troubadour song, anachronistically, since the troubadours flourished more than two centuries before Villon. But Pound thought that the troubadours found melodic lines so sensitive to the words that they became an ideal for all future music to follow. The instrumentation is strange: the first song in Le testament employs (among other things) a 
saxophone, a cymbal, a tambourine, a drum, a bassoon, and a cello, but these instruments do little, except occasionally to repeat a note or a series of notes from the vocal line, usually on the same pitch. The instruments seem less to accompany the voice than to alter the type-face of the voice, so to speak. As Pound wrote at the beginning of the score, "The 'orchestration' in the first part of the opera is not in the usual sense 'musical.' It is simply an emphasis on the consonantal $\&$ vowel sounds of the words" $(Y C)$.

Sigismundo was a contemporary of Villon, on a higher social plane, but equally engaged with sex, religion, and death. Instead of excerpts from testamentary poetry, Pound provides for his "score" the documents that constitute Sigismundo's testament--his generosity to painters such as Piero della Francesca, his consultation with Alberti on the architecture of the unfinished (but still preserved) Tempio. Instead of cello and bassoon, Pound provides cues that establish the right timbre, the right roughening of voice: the poet's own macho zest for combat ("we had smashed at Piombino and driven out"-- $C \mathrm{X} / 46$ ) or explicit judgments about Sigismundo's accomplishment, as when Pound visits what is left of the Tempio at notes, "The filigree hiding the gothic, / with a touch rhetoric in the whole" ( $C$ IX/41). Perhaps this will serve as a judgment on the Cantos as well as on the Tempio that seems a stone metaphor for the Cantos. The typographical novelties of the Canto are addressed to the ear more than to the eye: the page layout is designed to influence the reader's perception of vocal tone:

ALL typographic disposition, placings of words on the page, is intended to facilitate the reader's intonation, whether he be reading silently to self or aloud to friends. Given time and technique I might even put down the musical notation of passages or "breaks into song." (L, p. 322)

In Canto LXXXI there is a passage marked Libretto in the margin; and perhaps the whole series, from Canto I on, has an odd look because it is the word-book of an unwritten opera or Singspiel.

The Sigismundiad is one of the most impressive sequences in the Cantos, and many readers perhaps wish that Pound could have written more passages like it; but Pound was restless 
for new compositional methods as well as new subjects, and he moved on.

\section{Cantos XII-XVI}

By 1922, Pound realized that his project had outgrown the earlier Cantos, especially the Three Cantos of 1915, and he needed to find a new beginning: "up to now it has been mainly hash, necessary beginning if I am to reconstruct the various ichthiosauri that I need later in the poem" (P/F, p. 63). And in 1922 and 1923 Pound wrote a burst of new Cantos and revised the old Cantos for publication--though A Draft of XVI Cantos was not published until 1925. Canto VI was substantially rewritten. Three Cantos III was stripped down to the translation of Odysseus's descent into the underworld and the flurry of images at its end, and turned into the new Canto I; the Canto VIII of 1922 became the new Canto II; and Three Cantos I and II were erased almost entirely, except for a few terse passages--chief among them the proclamation that anyone who helped El Cid would be beheaded--gathered up into the brief new Canto III. But Pound would keep an eye on the unused parts of Three Cantos for the rest of his life: when he needed an ichthyosaurus, there was always a fossil at hand in Three Cantos.

The final Cantos of $A$ Draft of XVI Cantos show Pound ranging far in space and near in time. It is probable that he transposed Canto VIII in Canto II because it was part of mythological antiquity, and he thought that the first sixteen Cantos should a certain tendency to lurch forward in chronological order: the present ceaselessly interrupts the past, and the past ceaseless interrupts the present, but Canto I begins with Homer, Cantos V-VI treat the middle ages (the troubadours and Eleanor of Aquitaine), Cantos VIII-XI treat the Renaissance (Sigismundo), and Canto XVI ends with the Great War of 1914-1918. Acoetes must come to Bayswater: what began in myth must end with the mundane. The contemporaneity of many of the Cantos of 1923 may owe something to The Waste Land: Pound, like Eliot, needed modern England to serve as a terminus for the deformations and degradations of history. 
The Waste Land also seems related to the peculiar fable in the second half of Canto XII: the Tale of the Honest Sailor, who was persuaded that a baby had been taken out of his belly after he landed in the hospital, drunk--the sailor reformed himself, raised the lad and sent him to college, and confessed on his deathbed:

"I ain't your dad, no,

"I am not your fader but your moder," quod he,

"Your fader was a rich merchant in Stambouli" (C XII/17)

Pound also mused on the notion of male birth in a letter to Eliot from the end of 1921, describing Pound's midwifery on The Waste Land:

The are the poems of Eliot

By the Uranian Muse begot;

A Man their Mother was,

A Muse their Sire. (L, p. 170)

Perhaps the Cantos are also the children of a man's womb--as Pound noted, also in 1921, "the brain itself, is . . only a sort of great clot of genital fluid" (PDD, p. 203). The Honest Sailor is the most trivial version in the whole Cantos of the sailor-figure, Odysseus and Acoetes reduced to the stick figure of a dirty joke; but insofar as the Cantos attempt to be the total story of mankind, as that story impinged on Pound's intelligence--the epic not of a particular culture but of the whole race--the Honest Sailor, too, plays his part. Canto XII has been cited for introducing humor into the Cantos. This may not be quite correct: there is much humor in the earlier Cantos, and it is possible that the passage in Canto $\mathrm{V}$ about the dreitz hom Pierre de Maensac, with its laborious and obfuscated parallelisms, was intended to be a kind of selflampoon even before Amy Lowell got her hands on it. But Canto XII does tell the first sustained joke in the Cantos--it is to the Cantos what the song of the drunken Bozo is to Le Testament, a comic routine. Canto XII has the rich Amurrikan voice of "Jim X..." (John Quinn) to ape the sailor's low accent; Le testament has trombones to perform Bozo's farting and belching for him. 
The navigator of the Cantos takes a brief detour to China, in Canto XIII, to hear the wisdom of Confucius:

If a man have not order within him

He can not spread order about him ...

And said nothing of the "life after death."

And he said

"Anyone can run to excesses,

It is easy to shoot past the mark,

It is hard to stand firm in the middle." ( $C$ XIII/59)

This is one of the first voices in the Cantos to promote social order from a rational, secular perspective, rather than from the sensitive man's attempt to align himself with divine energies-even Sigismundo Malatesta was a visionary, who attempted to realize in architecture a dream of pagan gods. During the early 1920s Pound was starting his research into economics: and Confucius is the ancestor of all those sane monetary thinkers--sane by Pound's lights--such as C. H. Douglas, whose prescriptions for reform would decorate many later Cantos. History can look for correction to some transcendental realm; or history may have a mechanism for selfcorrection, if the Confucian voices are properly heard.

And now, having looked from West to East, having looked from past to present, Pound was ready for hell and purgatory. Cantos XIV and XV are an immensely accelerated Inferno; Canto XVI is a Purgatorio. It is as if Pound had spent the first thirteen Cantos slowly creeping up to Dante, and then had exhausted two-thirds of the Divine Comedy in a few lines. Pound's reason for drastically foreshortening the tour of the less comfortable parts of the afterlife was perhaps a simple one: for Dante, hell is eternal and immutable, a sculptural frieze; but for Pound, hell is incapable of sustaining itself, a state that is always collapsing, a sort of liquid dung that falls through the fingers that try to grasp it. Samuel Beckett remarked of Joyce's Finnegans 
Wake that the Modernist purgatory is different from the Medieval: "Dante's is conical and consequently implies culmination. Mr Joyce's is spherical and excludes culmination” (Disjecta, p. 33). Pound's hell is like Joyce's purgatory, an endless directionless slosh of movement, a dissolving that never quite falls into complete dissolution.

For Dante, a canto in hell entailed a teasing scene--why is this man carrying his head in his arms?--followed by a clear explanation of the crime and the punishment:

Goes on that headless trunk, that bears for light

Its own head swinging, gripped by the dead hair,

And like a swinging lamp that says, "Ah me!

I severed men, my head and heart

Ye see here severed, my life's counterpart.” (P, 1926, p. 156)

(This is Pound's paraphrase, from "Near Perigord," of Bertrans de Born's speech in Inferno XXVIII, 11. 118-42). But for Pound, the denizens of hell had lost most of their identities--even their names have almost eroded away:

The stench of wet coal, politicians

$\ldots \ldots \ldots$ and $\ldots \ldots$ n, their wrists bound to their ankles,

Standing bare bum,

Faces smeared on their rumps,

wide eye on flat buttock,

Bush hanging for beard,

Addressing crowds through their arse-holes,

Addressing the multitudes in the ooze,

newts, water-slugs, water-maggots ... (C XIV/61)

As Pound commented, "Even the XIV-XV has individuals in it, but not worth recording as such . .. [An editor] tried to get the number of ....... correct in each case. My "point" being that not even the first but only last letters of their names had resisted corruption" ( $L$, p. 293). The dots in 
the passage cited above stand for "Lloyd George" and "Wilson"--whose resolution of the first world war Pound considered a loathsome capitulation to the interests of profiteers.

Pound is here operating in the mode of the Dionysus of Canto II, who transformed the slave-traders into fish: Pound squashes Lloyd George and Wilson into a fitting shape. In this extremely disarticulated place, the distinction between buttocks and head has vanished: the politicians have been (so to speak) folded in two and then flattened in a steam press. The limit of monstrousness in Pound's imagination is the displacement of sense organs--eye on buttock, tongue in anus--as the human form turns into a jumble, a plate of spaghetti. The Cantos make up a poem about voices, and here human voices have turned into farts, simulations of oratory with intestinal gas, a complete disarticulation of speech. At the bottom of the Inferno, only a few feet from Satan himself, Dante placed Nimrod, a giant sunk to his waist in the frozen ground, babbling incomprehensible words because he had built the impious Tower of Babel and forever shattered the integrity of language (Inferno XXXI): but for Pound all the residents of hell are Nimrods, uttering meaningless noise, "the arse-belching of preachers" $(C \mathrm{XIV} / 63)$.

Hell is, to some degree, a bad bank. It is full of "usurers squeezing crab-lice . . . obstructors of distribution" ( $C \mathrm{XIV} / 63)$--usury, to Pound, was the attempt to create profit without increase of labor or commodities or any true value; the entropy of money. The excrementitiousness of money, a thesis dear to Freud, has rarely been presented so vividly as in Pound's Cantos. But hell is chiefly a bad printing press. The loudest noise in Pound's hell seems to be "howling, as of a hen-yard in a printing-house, / the clatter of presses, / the blowing of dry dust and stray paper" ( $C$ XIV/61-62). The great theme of the hell Cantos is the degradation of language, both spoken and written. Through the first thirteen Cantos, Pound sought and displayed the most potent texts and voices he could find; here Pound mangles, smears, unwrites, unspeaks, the texts and voices that need to be consigned to oblivion.

Finally, in Canto XV, the tourist Pound uses a clever optical trick to escape from hell: with a mirror, Medusa's petrifying gaze is angled down to the ground, creating a solid path amid 
the general diarrhea. It is a proof of the power of light to resist mud. In Canto XVI, we emerge from the "hell mouth" onto a

$$
\text { dry plain }
$$

and two mountains;

On the one mountain ... in hard steel

The road like a slow screw's thread,

The angle almost imperceptible,

so that the circuit seemed hardly to rise; $(C \mathrm{XVI} / 68)$

The mount of Purgatory climbs toward heaven at a rate so slow that it may be no ascent at all. The Canto goes on to reminiscences of those who fought in the Great War, those who died, such as Gaudier-Brzeska ("they killed him / And killed a good deal of sculpture"--C XVI/71) and T. E. Hulme, and those who lived, such as Wyndham Lewis and Hemingway. These names have not been effaced: Pound memorializes them. But the purgatory of the war kills or cripples or leaves unharmed, not according to any principle of moral consequence, but at random. It hard to be sure whether this is a fault in Pound's ethical design of the Cantos, or whether he meant to imply that, in the twentieth century, we have reached a state beyond even the possibility of justice.

\section{Cantos XVII-XXIII}

A Draft of XVI Cantos does not finish strongly, but the ending has a certain cliffhanger quality: here is hell, here is purgatory--now where is heaven? This was a question that Pound was not prepared to answer directly. But he was full of energy to write, and the next seven Cantos followed quickly: Cantos XVII-XXIII were all written by March 1925.

Canto XVII begins with an explosion of Dionysiac energies: "So that the vines burst from my fingers . . Z ZAGREUS! IO ZAGREUS! . . the goddess of the fair knees . . . with white 
hounds / leaping about her" ( $C$ XVII/76). But soon we are in Venice, exceedingly beautiful, with its gilt beams, its dye-pots in the torch-light, its "trees growing in water, / Marble trunks . . . The light not the light of the sun" ( $C \mathrm{XVII} / 76)$. Nothing in this depiction is Venice is specifically ominous or morbid, and yet there is an undertone of artificiality, of surrogation: marble columns have replaced tree-trunks. The placement of Canto XVII makes the reader look for paradise: but Canto XVII neither offers paradise nor refuses paradise--it simply gives something that is like a paradise. The notion of substitute paradises will dominate the Cantos from this point on.

As early as Three Cantos III, there is a false paradise:

Another's a half-cracked fellow--John Heydon, Worker of miracles, dealer in levitation, In thoughts upon pure form, in alchemy, Seer of pretty visions ("servant of God and secretary of nature");

Full of a plaintive charm, like Botticelli's, With half-transparent forms, lacking the vigor of gods. (Bush, Genesis, p. 67) Heydon seems to possess divine revelation--but his gods are mere wraiths, like the "Gods of the wingèd shoe" in Pound's "The Return" (1912), who "hesitate . . half turn back . . pallid the leash-men!" $(P, 1926$, p. 74). Similarly, in Canto XX, Pound presents the lotus-eaters, who have given up Odysseus's troublesome voyage and dwell in a parody of heaven:

Shelf of the lotophagoi,

Aerial, cut in the aether.

\section{Reclining,}

With the silver spilla,

The ball as of melted amber, coiled, caught up, and turned.

Lotophagoi of the suave nails, quiet, scornful, Voce-profondo: 
"Feared neither death nor pain for this beauty;

If harm, harm to ourselves." (CXX/93)

Here is a society consisted entirely of Mauberleys: tensionless aesthetes, or anesthetes, too drowsy and bored, etherized, to be efficient sensualists. Increasingly Pound was suspicious of those who liked art, not for the sake of divine apprehension, but for art's own sake:

The best Egyptian sculpture is magnificent plastic; but its force comes from a non-plastic idea, i.e. the god is inside the statue.

I am not considering the merits of the matter, much less those merits as seen by a modern aesthetic purist. I am using historic method. The god is inside the stone . . ( $L E$, p. 152).

The greatest threat to paradise seems to lie in aesthetical feignings of it. But it is not clear that Pound could seize heaven more confidently than those visionaries whom he deplored.

Canto XX offers a rare case of a Canto for which Pound offered his own glosses and interpretation, in a letter to his father:

Nicolo d'Este in sort of delirium after execution of Parisina and Ugo. . . V Various things keep crossing up in the poem. The original world of the gods; the Trojan War, Helen on the wall of Troy with the old men fed up with the whole show and suggesting she be sent back to Greece. ...

Then in the delirium Nicolo remembers or thinks he is watching death of Roland. Elvira on wall or Toro (subject-rhyme with Helen on Wall)... . The whole reminiscence jumbled or 'candied' in Nicolo's delirium. Take that as a sort of bounding surface from which one gives the main subject of the Canto, the lotophagoi: lotus eaters, or respectable dope smokers; and general paradiso. You have had a hell in Canti XIV, XV, purgatorio in XVI etc. (L, p. 210)

Niccolò d'Este married a very young woman, Parisina Malatesta (a cousin of Sigismundo's), but discovered she was sleeping with his own illegitimate son, Ugo--and so he had them both killed. 
It is not surprising that Pound would think to intercut this tale with allusions to other beautiful wives who ran off with attractive men, from Helen and Paris onward; what is surprising is his announcement that such affiliations are part of a psychological process, a delirium within a persona. He seems to be returning to the mode of the Three Cantos of 1915, with the role of the matrix-intelligence being played by Niccolò, instead of Pound himself. But Pound has taught us too well in the intervening years: we read this Canto (unless coached to do otherwise) as a flat surface, or a montage of flat surfaces, in which Niccolò and Helen of Troy and Charlemagne's brave Roland all cohabit on the same plane. Pound evidently felt that he could establish Niccolò as a controlling sensibility, flowing over and around the rest of the material in the Canto; but he did nothing to bring Niccolò far enough into the poem's foreground to achieve that effect. And the invitation to regard Canto $\mathrm{XX}$ as a prince's delirium, or as a construct of dope smoking, is also an invitation to deride Pound himself. Just as it is dangerous to announce that the Cantos are a rag-bag, so it is dangerous to announce that the Cantos are a fever dream. It is odd that Pound would have chosen to interpret Canto XX, because this very Canto begins with an affirmation of the inexplicability of old texts: Pound records a visit to a Professor Lévy, the World's Leading Authority on Provençal--he asked Lévy what Arnaut's word noigandres means, only to be told that Lévy used to ask himself every night, "'Now what the DEFILL can that mean!'” $(C X X / 90)$. Pound asks the questions of his readers for us.

The lotus-eaters offer a false relief from the torment of Niccolò's existence, an Ersatz of paradise. Paradise is one major theme of Cantos XVII to XXIII; another is economics. This set of Cantos is full of munitions-merchants and exploiters of labor; their patron saint appears near the beginning of the sequence:

And of Kublai:

"I have told you of that emperor's city in detail

And will tell you the coining in Cambaluc

that hyght the secret of alchemy: 
They take bast of the mulberry-tree,

That is a skin between the wood and the bark,

And of this they make paper, and mark it

Half a tornesel, a tornesel, or a half-groat of silver ...

And all this costs the Kahn nothing,

And so he is rich in this world. ( $C$ XVIII/80)

Pound took this from Marco Polo's account of his voyage to Cathay. It should be noted that Kubla Khan, who appears in Coleridge's poetry as the builder of Xanadu, appears in Pound's poetry as a debaucher of currency. Pound liked to rectify the errors of romantical poets: in 1959 Pound quoted genuine documents of Justinian's Constantinople ("Mr Yeats called it Byzantium," C XCVI/681), setting forth the penalties for selling wine at false measure, or for building a wall that falls down--as if Pound were showing that civic magnificence could be achieved honestly through a good law code, instead of existing precariously in the dreams of an ignorant poet. Coleridge's Kubla Khan has dwindled to Kubla Kahn, as if he were an early member of Pound's Jewish Banking Conspiracy.

Just as paradise is difficult to find in a welter of substitute paradises, so money is confounded by substitute money. In A Draft of XVI Cantos, it is usually quite easy to tell the light from the mud; but from Canto XVII evaluation, discrimination, start to become far more difficult. We are still in purgatory, though teased by gorgeous glimpses that may or may not have something to do with heaven.

\section{Cantos XXIV-XXX}

Between 1925 and 1928, Pound wrote Cantos XXIV-XXVII, and then published all the Cantos written after A Draft of XVI Cantos as A Draft of the Cantos 17-27 (1928). Cantos XXIV-XXVII begin by recounting more of the life of Niccolò d'Este--his Odysseus-like travels 
through the Mediterranean, his subtlety and benevolence as a ruler--but the main theme of these Cantos is Venice: Pound, like many other poets, was attracted to the spectacle of Venice sinking into Adriatic slime as a metaphor for the foundering and decay of old glory. There is some light in these Cantos, but a great deal of mud: the degeneration of the guild spirit of good craftsmanship, the degeneration of the painter's relation to his patron, the degeneration of painting itself.

But in some respects this period was more notable for Pound's explanations of Cantos than for the Cantos themselves. During 1927-28 Pound made the most intense effort to understand what he had done, and what he was trying to do. In 1927 he wrote to his father:

Afraid the whole damn poem is rather obscure ... Have I ever given you outline of main scheme ::: or whatever it is?

1. Rather like, or unlike subject and response and counter subject in fugue.
A. A. Live man goes down into world of Dead
C. B. The "repeat in history"
B. C. The "magic moment" of moment of metamorphosis, bust thru from quotidien into "divine or permanent world." Gods, etc. (L, p. 210)

It is likely that Pound devised this scheme by noting that the first two Cantos displayed (1) a descent into hell and (2) a metamorphosis, in which the normal world buckles and the divine world breaks through. As for the third element, the "repeat in history," it is certainly the chief constructive principle of the Cantos: the achronological superposition of stories with common formal elements, such as married women abducted by handsome young lovers. Later in this letter Pound explicated Canto XX (as cited above), and used the phrase "subject-rhyme": a fascinating term, implying that Pound has displaced the principle of rhyme from the level of phonics to the level of theme: history itself displays a structure of echoes, a sort of stanza form. As early as 1912 Pound discovered that a landscape in southern France could shape itself in the manner of a poem: 
The r[oa]d. to Celles is indeed a sort of sestina, of cusp \& hills, of prospects opened \& shut, or round trees \& poplars aligned.

sestina vs. recurrence in nature. (WTSF, p. 15)

A sestina is a poem in which the same six words, falling at the line-ends of each six-line stanza, reappear in a different order in the subsequent stanzas. The route's varied monotony--hills alternating with valleys, round trees alternating with tall thin poplars--made Pound conceive the road to Celles as a kind of landscape-projection of the sestina: the even recurrence of trees and hills seemed a prosody of objects, rising and falling like the stressed and unstressed syllables of a line of poetry. In some sense the Cantos, as Pound conceived them in 1927, are to history what this landscape is to geography: a mapping of recurrence in time, heard as a subtle chiming, as if history were an endless troubadour song, a huge canto. The tripartite design of descent into "world of Dead" (hell), "bust thru from quotidien" (heaven), and "repeat in history" (our world-or purgatory) suggests that there is a whole divine comedy in every Canto, all mixed up together.

Pound's use of the word fugue is also fascinating. Pound's opera Le testament is fugueless, almost completely without counterpoint of any sort--indeed Pound's major musical interest so far had been the troubadour song, with its single vocal line. And he conceived the earlier Cantos either as collages of pictures or as successions of voices. But now he wanted to hear the voices in the Cantos, not as taking regular turns, but as sounding all at once, in an overlapping vocal polyphony. While the metamorphosis begins, the descent to the underworld continues; while the voice of Jim X... tells the story of the Honest Sailor, the voice of Sigismundo continues somewhere in the background. Pound strains his ear to to grasp history ahistorically, as a chorus of voices all of which are co-present, contemporaneous.

But if Pound hoped that a fugal model of the Cantos would impart a satisfying form to the whole project, he was mistaken. As the musicologist Donald Tovey has noted, a fugue is not a form, but a texture: "The first thing to realize about fugue is that it is a medium, like blank verse, not a thing, like a rondo" (Symphonies and Other Orchestral Works, p. 17). It requires 
extraordinary art to make a satisfactory fugue, but the art is a local art, an art of arranging overlaps in a pleasing manner, not a global art. It is the sort of art that a poet gifted at writing lyrical miniatures, like Pound, could employ to produce one of the longest poems in the language. Pound may have been aware, however, that the hope that the Cantos would become a rounded, polished, formally satisfying whole was a forlorn hope: the year after he described the tripartite scheme to his father, he wrote: "I am not going to say: 'form' is a non-literary component shoved on to literature by Aristotle ... But it can do us no harm ... to consider the number of very important chunks of world-literature in which form, major form, is remarkable mainly for its absence" (LE, p. 394).

In February 1928 Pound tried to explain the Cantos to Yeats, who remembered his explanation as follows:

For the last hour we have sat upon the roof ... discussing that immense poem ... I have often found there brightly printed kings, queens, knaves, but have never discovered why all the suits could not be dealt out in some quite different order. Now at last he explains that it will, when the hundredth canto is finished, display a structure like that of a Bach Fugue. There will be no plot, no chronicle of events, no logic of discourse, but two themes, the Descent into Hades from Homer, a Metamorphosis from Ovid, and, mixed with these, mediaeval or modern historical characters. . . He has scribbled on the back of an envelope certain sets of letters that represent emotions or archetypal events--I cannot find any adequate definition--A B C D and then J K L M, and then each set of letters repeated, and then A B C D inverted and this repeated, and then a new element X Y Z, then certain letters that never recur . . . and all set whirling together. (A Vision, pp. 3-5) Pound was exasperated with the attention that Yeats's description received: "CONFOUND uncle Bill YEATS' paragraph on fuge ... more wasted ink due his 'explanation,' than you cd. mop up with a moose hide" (P/I, p. 35). Yeats was not always a reliable reporter, but there seems little reason for doubting Yeats's account. Yeats's word "whirling" recalls the vorticism of the mid- 
1910s, when the Cantos began; Yeats's phrase "no logic of discourse" recalls many of Pound's statements on the anti-discursive qualities of the art he espoused; and the notion of a fugue has the sanction of Pound's letter to his father. What is new in Yeats's account is the concept of retrograde permutation: first $\mathrm{A} B \mathrm{C} \mathrm{D}$, then $\mathrm{D} \mathrm{C} \mathrm{B} \mathrm{A}$.

Retrograde is a certainly a manner of defeating chronology: if order is so arbitrary that the elements can be placed indifferently forward or backward, then time's arrow is blunted. But the Cantos were slow to emancipate themselves from clock and calendar: many sequences, including A Draft of XVI Cantos, show a distinct chronological structure; and, although the later Cantos are sometimes more adventurous, it is often possible to establish a sort of base-epoch for a Canto or for a sequence of Cantos.

There is another consequence of retrograde permutation, besides destabilizing the timeline: it also tends to levitate the Cantos, to make them joky, impudent. It is potentially a technique for dissolving the solidities in the material it treats:

A definite philosophical act ... was performed along in 1916 to '21 by, as I see it, Francis Picabia. If he had any help or stimulus it may have come from Marcel Duchamp

Voltaire used a sort of reductio ab absurdum for the destruction of hoakum. Picabia got hold of an instrument which cleared out whole racks full of rubbish.

"Europe exhausted by the conquest of Alsace Lorraine." The transposition of terms in idées reçues. The accepted cliché turned inside out, a, b, c, d; being placed

$$
\begin{aligned}
& \text { b, d, c, a, } \\
& \text { c, b, d, a, etc., in each case }
\end{aligned}
$$

expressing as much truth, half truth or quarter, as the original national or political bugwash.

That anyone shd. have tried to use Picabia's acid for building stone, shows only the ineradicable desire of second-rate minds to exploit things they have not 
comprehended. (GK, pp. 87-88)

Of course, the transposition of the terms of history itself is far more ambitious than the transposition of the terms of a cliché: it is one thing to say, "conquest exhausted by the Alsace Lorraine of Europe"; it is another thing to scramble the chronology of four thousand years of epic events in the search for an achronological pattern. And yet there is a sense in which we can take the Cantos as a Dada project: insofar as Pound accepted a model of the Cantos based on permutation, a tendency toward acid satire would become manifest. Pound surely wanted to build stone, build a new Tempio through the Cantos, as well as to eat away the old stone of worthless things. But it is no accident that, in the late 1920s, at the very moment when he conceived the Cantos according to a somewhat Dadaist model, he wrote a series of burningly satirical Cantos--deconstructions, not constructions; and it is no accident that, at the very moment when he conceived the Cantos as a fugue, the Cantos start to resound with music more loudly than after before. Music and satire become explicit, as Pound's new model for what he had done started to influence what he was doing.

The most striking music in the whole Cantos--perhaps in all Modernist poetry--occurs in Canto XXV:

Form, forms and renewal, gods held in the air, Forms seen, and then clearness,

"as the sculptor sees the form in the air...

"as glass seen under water ...

and saw the waves taking form as crystal, notes as facets of air, 
and the mind there, before them, moving, so that notes needed not move. $(C \mathrm{XXV} / 119)$

The music seems to freeze before the poet's eyes into visible sine waves, vitreous, glistening, a string of swells and tapers like a necklace of translucent cowrie shells. This arrested sound-wave can be studied, like sculpture, from any angle: a reified audibility, comprehended into a breathless instantaneity of being. In a fugue all the musical material tends to be co-present; and in this Canto, melopoeia, the poetry of the musical phrase, turns into phanopoeia, the poetry that casts images before the visual imagination.

The later Cantos in this sequence become less explicitly musical, more satirical. In Canto XXVII, the Xarites--the Graces--confront tovarisch--the comrade, a plodding, strictly political man, who "wrecked the house of the tyrants" ( $C$ XXVII/131) and seems unable to respond to the antique lovelinesses that hover over him; this is a Canto not about building stone, but about smashing it. In Canto XXIX, Pound presents a young numbskull named Juventus, also tantalized by glimpses of the glories beyond the earth:

"Matter is the lightest of all things,

"Chaff, rolled into balls, tossed, whirled in the aether . .

"Light also proceeds from the eye;

"In the globe over my head

"Twenty feet in diameter, thirty feet in diameter

"Glassy, the glaring surface ... (C XXIX/143)

(But Juventus ultimately ignores these highfalutin visions in favor of the jazzband playing on the "pornograph.”) This aria constitutes an all-too-close-for-comfort spoof of Neoplatonic transcendentalisms from Pound's The Spirit of Romance (SR, p. 92) and elsewhere. The more closely Pound approaches a Dadaist model for the Cantos, the more desecrated the whole project becomes: even Pound's own holy things start to grow farcical before his acid gaze.

In 1930 Pound decided to gather A Draft of XVI Cantos, A Draft of the Cantos 17-27, and 
three new Cantos into a summary volume, the accomplishment of fifteen years of work: A Draft of XXX Cantos (1930). The last Canto in this group feels like an ending: instead of the farce of some of these Cantos preceding, Canto XXX is sober and clear. It presents the major antitheses of the Cantos--light and mud--as two great personifications: Artemis, a goddess cleansing the world of foulness, in a Chaucer-like "Compleynt . . Agaynst Pity" ( $C$ XXX/147); and Madame $\sim$ K7/ (Hyle, Gr. for wood or matter), who stands for the materiality of the world, all opacity, resistance to illumination, love of death; her chief worshiper seems to be Pedro, the fourteenthcentury Portuguese king, who dug up the skeleton of the woman he loved and set it on the throne beside him. Pound originally told this story in Three Cantos II--and its position at the end of $A$ Draft of XXX Cantos suggests the degree to which the whole Cantos whirligig out of the original version of 1915 .

But the last part of Canto XXX is devoted, not to Artemis and Madame $\sim \mathrm{K} 7 /$, but to a document about the development of the cursive type-face in 1503--a means for turning printed books into works of art. Pound concludes this huge installment of his life's work with typography: just as Sigismundo controlled all the decoration of his Tempio, devoted to the old gods of Greece and Rome, so Pound controls the appearance of his private Tempio, the printed book that the reader holds in hand. The Cantos threatened to disperse into the fluid permutation of fleeting elements, A B C D and X Y Z; but at the end of this large sequence the project once again aspires to weight, solidity of design.

\section{Cantos XXXI-XI}

Eleven New Cantos XXXI-XLI (1934) followed quickly after A Draft of Thirty Cantos; after Pound clarified his method and his themes to himself, he could work faster, it seemed. One of the chief accomplishments of this series was the establishing of an eleven-canto sequence (what Pound would call a decad) as the basic chunk in which new Cantos would appear. The 
"major form" of this decad is simple, but effective: these eleven Cantos pivot around Canto XXXVI, the middle Canto, which has a texture far different from the five before it and the five after it.

The first five Cantos take the arch of the Venetian sequence XXIV-XXVII and transpose it to America: Pound tells the story of the flowering of genius among the early American presidents, and the subsequent decay. We hear the inquisitive, well-educated, very adultsounding voices of Adams, Jefferson, John Quincy Adams: studying European architecture, planning canals, civilizing the Indians, finding rice and turnips adapted to the American climate. But the focus of the American shaping intelligence soon starts to blur, and little corrupt leaders-Clay, Calhoun,Webster--start to take over; soon we are in the world of child labor, mud, and mid-European stupidity, coarseness, and venality; at the end of this group, Madame $\sim \mathrm{K} 7 /$ herself puts in an appearance, all tarted up ( $C \mathrm{XXXV/175).}$

The transition from Canto XXXV to Canto XXXVI is one of the most startling in the whole project. Instead of heavy Jewish accents, and descriptions of heavy tolls on heavy cargoes, we have this:

A lady asks me

I speak in seaon

She seeks reason for an affect, wild often

That is so proud he hath Love for a name...

Where memory liveth

it takes its state

Formed like a diafan from light on shade . . .

Cometh from a seen form which being understood

Taketh locus and remaining in the intellect possible

Wherein hath he neither weight nor still-standing,

Descendeth not by quality but shineth out 
Himself his own effect unendingly ... (C XXXVI/177)

This is a translation of a poem that Pound had been laboring to translate since his youth, Guido Cavalcanti's canzone, Donna mi priegha. The calm intensity of this poem makes it the axis of Eleven New Cantos, the still point in its turning world. Guido's canzone describes with extreme subtlety--indeed so subtly that Pound himself never claimed fully to understand the whole poem-the psychic processes through which Love imprints itself on the memory; how Love fills the whole mind with love, a self-generating motive force. The psychological inwardness of Canto XXXVI sets it apart; it might be conceived as a complement to all the other Cantos Pound ever wrote, in that it describes the mind's receptivity to those divine energies, those dazzles that intermit the gloom. Here we have a cool subjectivization of the gods; this Canto corresponds to the other Cantos as persona corresponds to images--a mental device for assimilating the glories at the edge of the visual field.

Canto XXXVI provides only a brief respite from "'The fifth element: mud"" $(C$ XXXIV/166). By Canto XXXVII we are back in America, amid the snarlings and yelpings of the financiers, and their political stooges, eager to deprave the American economy by manipulating the second National Bank. And in Canto XXXXIII the munitions-sellers will return, to foment war and increase useless consumption of goods. But the last five Cantos have a different texture from the first five: instead of a fairly steady fingering-through-documents that illustrate the triumph and decline of American, the last five Cantos are riddled with rays of light, from a variety of plausible paradises. For example, Cantos XXXVIII offers a peculiar glance at Marconi, kneeling before the Pope:

(and the Pope's manners were so like Mr Joyce's ... )

Marconi knelt in the ancient manner

like Jimmy Walker sayin' his prayers.

His Holiness expressed a polite curiosity as to how His Excellency had chased those 
electric shakes through the a'mosphere. (C XXXVIII/187)

The Pope ought to be an expert in spiritual transmission and reception--but Marconi seems to have replaced him. This whole passage is satirical, very much in the mode of Hugh Selwyn Mauberley: we have the press for wafer, franchise for circumcision, and radio waves for beams of divine guidance. But Pound took electromagnetic radiation (at least half seriously) as a method of conceiving the pagan gods appropriate to the limited bandwidth of the Modernist intellectual spectrum:

We appear to have lost the radiant world where one thought cuts through another with clean edge, a world of moving energies 'mezzo oscuro rade' ["Disjunct in mid darkness"], 'risplende in se perpetuale effecto' ["shineth out / Himself his own effect unendingly"], magnetisms that take form, that are seen, or that border the visible, the matter of Dante's paradiso, the glass under water, the form that seems a form seen in a mirror ...

For the modern scientist energy has no borders, it is a shapeless 'mass' of force; even his capacity to differentiate it to a degree never dreamed by the ancients has not led him to think of its shape ... The rose that his magnet makes in the iron filings, does not lead him to think of the force in botanic terms ...

A medieval 'natural philosopher' would find this modern world full of enchantments, not only the light in the electric bulb, but the thought of the current hidden in air and in wire would give him a mind full of forms, 'Fuor di color' ["out from colour'] or having their hyper-colours. The medieval philosopher would probably have been unable to think the electric world, and not think of it as a world of forms. ( $L E, \mathrm{p}$. 154)

This is from a section, written in 1928, of Pound's essay on Cavalcanti; the bracketed translations of Guido's Italian inserted in the text are taken from Canto XXXVI. Potentially Marconi's radiowaves can stimulate divine excitements, in those who possess sufficiently sensitive antennae; 
but, as so often in Cantos XVII-XXX, it is not certain what is parody and what is paradise.

As the decad comes to a close, Pound orients the sequence by referring it back to the original themes of Cantos I and II: Odysseus on his way to the underworld, and the metamorphosis or "bust thru." These two are combined in Canto XXXIX, adapted from Homer's account of Odysseus's sojourn with Circe, and figured with some of Homer's original Greek. It is likely that Canto XXXIX demonstrates how the tripartite scheme of Pound's letter of 1927 was starting to control the actual substance of the Cantos written after it. Still, the Odysseus of Canto XXXIX has altered considerably from the sober, intent, troubled, "Seafarer"-like character of Canto I. The Odysseus of the 1930s is a slangier, hipper, more casual, more cosmopolitan character entirely:

Fat panther lay by me

Girls talked there of fucking, beasts talked there of eating, All heavy with sleep, fucked girls and fat leopards,

Lions loggy with Circe's tisane $(C \mathrm{XXXIX/193)}$ Pound tended to become flippant with his major characters as his applications of the scheme of 1927 grew slightly mechanical; something similar may have happened to Joyce in the later stages of Ulysses, as he kept consulting the chart of his Homeric scheme. By 1938 Pound was calling the Homeric world "very human. The Odyssey high water mark for the adventure story, as for example Odysseus on the spar after shipwreck. Sam Smiles [a writer of pop self-help books] never got any further in preaching self-reliance" ( $G K$, p. 38). By 1955, when Pound wrote the Canto that treats Odysseus on the spar, he imagined Leucothea offering Odysseus a trade: "'my bikini is worth your raft"” $(C \mathrm{XCI} / 636)$.

But if Odysseus is growing more amusing, Pound's devotion to pagan ideals is growing more intense. Later in Canto XXXIX, Pound writes of a headland "with the Goddess' eyes to seaward / By Circeo, by Terracina, with the stone eyes" ( $C$ XXXIX/195). This passage restates Pound's "Credo" of 1930: 
Given the material means I would replace the statue of Venus on the cliffs of Terracina [a town on the Tyrrhenian sea, between Rome and Naples]. I would erect a temple to Artemis in Park Lane. I believe that a light from Eleusis persisted through the middle ages and set beauty to the song of Provence and of Italy. (SP, p. 53).

Pound considered that belief in Venus and Mars and Bacchus had never been exterminated by Christianity, but had maintained a clandestine existence throughout the centuries, occasionally flickering into public consciousness--in the songs of the troubadours, in the heretical Cathar religion attacked by Christian armies during the Albigensian Crusade of the thirteenth century, in the Tempio of Sigismundo. From the time of Three Cantos on, Pound conceived the Cantos as a reconstruing of history according to pagan terms--as if Pound could recreate a liturgy for Dionysus.

But the volume Eleven New Cantos ends on a note of secular, as well as religious, hope: Ma questo," said the Boss, "è divertente."

catching the point before the aesthetes had got there;

Having drained off the muck by Vada

From the marshes, by Circeo, where no one else wd. have drained it. (C XLI/202) The Boss is Benito Mussolini: Pound gave a copy of A Draft of XXX Cantos to il Duce, who consented to an audience with the poet; Mussolini told Pound that he found the Cantos diverting. This power of discernment impressed Pound more than it has impressed others, since "diverting" is a comment could be applied to almost any text; but Pound thought that Mussolini had recognized a fellow genius. Pound associated Circeo with Circe: for the purposes of the Cantos, the draining of the marshes of Circeo is equivalent to ridding the world of vile transformations; under the benign gaze of Mussolini, pigs are changing back into men. Wherever Pound looks, at the end of this most optimistic of all the batches of Cantos, he sees signs that, despite the general degradation, social virtue is taking hold in a few fortunate places: Mussolini's Italy; and a small 
town in Austria called Woergl (XLI/205), where the residents grew prosperous, while the surrounding towns were caught in poverty: the authorities issued their own local money, stamped with a date, which steadily lost value if hoarded and not spent. Pound thought that this measure would cure the problem of obstruction of distribution that had long bothered him: for money stamped, so to speak, with an expiration date quickly reverted to the empty paper that all paper money truly was. Money thereby lost its power of surrogation, its power to usurp labor and goods. But Pound did not yet seem much closer to a vision of paradise that was the real thing, and not a substitute.

Eleven New Cantos begins with Jefferson and ends with Mussolini. And in 1933, as he was finishing these Cantos, Pound wrote Jefferson and/or Mussolini, a treatise to make prose sense of the coordination between his two heroes. In this book, Pound made a remarkable connection between poetry and politics:

The real life in regular verse is an irregular movement underlying. Jefferson thought the formal features of the American system would work, and they did work till the time of General Grant but the condition of their working was that inside them there should be a de facto government composed of sincere men willing the national good. When the men of understanding are too lazy to impart the results of their understanding ... I don't believe it matters a damn what legal forms or what administrative forms there are in a government. The nation will get the staggers. (J/M, p. 95)

Just as Pound set up the principle of rhyme at an orthogonal to the usual axis--governing subject matter, not word-sounds--so Pound now conceives political as an irregular motion of accents underlying the regular prosody of official laws, administrative flow-charts. Just as Pound's verses exaggerate the hesitations and accelerations that underlie normal iambic verse, so Pound's Cantos attempt to seize the erratic compulsive movement of the intellectual lives of Jefferson, Adams, and other wise leaders--the source of real authority in early America. 
By 1934, when Eleven New Cantos was published, Pound had devised a new, or partly new, scheme for conceiving the Cantos: the ideogram:

But when the Chinaman wanted to make a picture of . . . a general idea, how did go about it?

He is to define red. How can he do it in a picture that isn't painted in red paint?

He puts ... together the abbreviated pictures of

\section{ROSE}

IRON RUST

\section{CHERRY}

FLAMINGO

That, you see, is very much the kind of thing a biologist does . . . when he gets together a few hundred or thousand slides, and picks out what is necessary for his general statement. Something that fits the case, that applies in all of the cases. ( $A B C R$, pp. $21-$ 22)

Pound had discovered this scheme for the ideogram in the notes of the sinologist Ernest Fenollosa--notes which Pound had used for his translations from Chinese and Japanese during 1914-16, and which he had edited and published as The Chinese Written Character as a Medium for Poetry. But in the 1930s Pound took new inspiration from these notes, and recommended them as an Ars Poetica (L, p. 322) and an instruction in thinking (J/M, p. 22). This model of the ideal poetic act--a signifying whole extrapolated from a heap of concrete particulars--helped Pound to explain what he had done, and also provided a dominant model for the Cantos to come, which are far more ideogrammatically self-conscious than Cantos I-XLI. There is a moment, though, near the end of this sequence, when we see ideogrammatic thinking at work. In a passage that ponders African and Arab languages, Pound noted:

Bruhl found some languages full of detail

Words that half mimic action; but generalization is beyond them, a white dog is 
not, let us say, a dog like a black dog.

Do not happen, Romeo and Juliet . . (C XXXVIII/189)

For some folks, a rose by any other name would not smell as sweet, because there is no such thing as a rose, only particular roses. Pound was starting to dream of an English like the language described here: a language with tremendous powers of evoking concrete action, but without generalization, except insofar as the reader's mind draws unmistakable inferences from minute particulars. In his "Vorticism" article of 1914, Pound spoke of certain generalizations as "'lords' over fact"--just as $(x-a)^{2}+(y-b)^{2}=r^{2}$ is not a particular circle, but the general form of all circles (EPVA, p. 207). But in many of the Cantos, Pound pursued the ideogrammatic method so remorselessly that he, essentially, asked facts to find ways of becoming lords over themselves.

He hoped that he could present rose, cherry, rust, and flamingo, and that he could then present the idea red with a devastating clarity. There are occasions in the later Cantos when he did. But there are other occasions when the reader is more likely to discover, not red, but a thorny flamingo-leg terminating in a curlicue of scrap iron--a futile mishmash. The ideogrammatic method--like the rag-bag method, the Noh play method, and the fugal method-did not solve all Pound's problems. Instead it created problems; but Pound's strength as a poet lay in his astonishing capacity for creating problems, without necessarily solving them.

At the bottom of the last page of Eleven New Cantos, Pound wrote "ad interim 1933" (C $\mathrm{XLI} / 206$ ). He thought that a time would come that was no longer in the meantime, a time when A Draft of $X X X$ Cantos would be simply $X X X$ Cantos. But of course all Pound's Cantos, past and future, were to be provisional Cantos. And it is in their improvisation that their power dwells. 